\title{
СУТНІСТЬ І СТРУКТУРА КІНЕЗІОЛОГІЧНОЇ КОМПЕТЕНТНОСТІ МАЙБУТНІХ ФАХІВЦІВ ФІЗИЧНОЇ КУЛЬТУРИ І СПОРТУ
}

\author{
(C) Красілов А.Д., 2019 \\ http://orcid.org/0000-0019-0253-0145 \\ http://doi.org/10.34142/2312-2471.2019.62.11
}

У статті обгрунтовано сутність та структуру кінезіологічної компетентності майбутніх фахівців з фізичної культури та спорту (ФКіС), яка формується та розвивається в процесі їхньої професійної підготовки. Кінезіологічна компетентність майбутніх фахівців фізичної культури та спорту розумісться як складова їх професійної компетентності, інтегральна особистісна якість, яка проявляється у поєднанні ціннісних поведінкових установок на раціональне виконання рухових дій $i$ прагнення до фізичного розвитку й саморозвитку, спеціальних (кінезіологічних) знань $і$ вмінь та методичних навичок їхнього розвитку в себе та інших, а також навичок рефлексї щуодо оцінки ефективності рухової активності. Під формуванням кінезіологічної компетентності майбутніх фахівців з фізичної культури та спорту розуміється динамічний процес якісних та кількісних особистісних змін у майбутніх фахівців ФКіС, щзо відбуваються з позицій їхньої мотивації до формування кінезіологічної компетентності як професійного пріоритету $у$ професійній діяльності та иүілеспрямованості в оволодінні спеціальними кінезіологічними знаннями та вміннями. Результатом такого формування $\epsilon$ цілісна особиста освіта, яка забезпечує ефективне вирішення професійних завдань майбутніми фахівиями ФКіС. Виділено гносеологічний (сприйняття, осмислення $i$ відображення кінезіологічних знань, а також біомеханічне моделювання рухової активності), праксеологічний (здатність конструювання прочесу навчання руховим діям та їх корекиії) та поведінковий (прагнення досконалості професійної діяльності у формуванні рухових дій, професійно необхідні особистісні якості для педагогічної взаємодії) компоненти.

Ключові слова: кінезіологічна компетентність, майбутні фахівці фізичної культури та спорту, формування кінезіологічної кмпетентності, кінезіологічні знання, кінезіологічні уміння.

Krasilov A. D. The Essence and Structure of Kinesiological Competence of Future Specialists in Physical Culture and Sport

The article substantiates the concept and structure of kinesiological competence of future specialists in physical culture and sports (PC\&S), which is formed and developed in the process of professional training. Kinesiological competence of future specialists in physical culture and sports is understood as a component of their professional competence, integral personal quality, which 
combines values of behavioral attitudes, desire for physical development and selfdevelopment, special kinesiological knowledge, professional kinesiological skills, abilities that ensure quality performance, professional tasks and contribute to the maintenance and promotion of human health. Under the formation of kinesiological competence of future specialists in physical culture and sports we understand the dynamic process of qualitative and quantitative personal changes in future specialists $P C \& S$, occurring in terms of their motivation to form kinesiological competence as a professional priority in professional activities and focused on mastering special kinesiological knowledge. The result of such formation is a personal education, which provides an effective solution to professional problems by future specialists $P C \& S$. The purpose of kinesiological competence formation of future specialists in physical culture and sports is to master the set of theoretical knowledge, practical skills and abilities about biomechanical bases of human motor activity, as well as pedagogical means and methods of its optimization to improve motor actions to achieve the planned results in physical education, sports, as well as in physical rehabilitation and recreation. The epistemological, praxeological and behavioral components are highlighted.

Key words: kinesiological competence, future specialists in physical culture and sports, components, kinesiological knowledge, kinesiological skills.

Постановка проблеми. Утвердження орієнтації пріоритетів сучасного українського суспільства на здоровий спосіб життя, поширення інноваційних видів рухової активності, розвиток спорту та рухової реабілітації, активна розробка «людино-машинних» систем, функціонування яких передбачає використання знань про механічні основи рухової активності людини, розвиток пристроїв, які дублюють втрачені рухові функції, збільшують м'язову силу тощо обумовлюють запит українського суспільства на професійну підготовку фахівців галузі фізичної культури і спорту (ФКіС), у яких буде сформовано знання про механіку людських рухів, особливості м'язового скорочення, вплив фізичних навантажень на розвиток сили м'язів верхніх та нижніх кінцівок, вміння раціонально здійснювати фізичні дії з певно, наприклад, оздоровчою метою тощо, тобто буде сформована відповідна кінезіологічна компетентність.

Значущість такого формування обумовлена результатами галузей біохімії спорту, фізіології, біомеханіки та психології спорту, опанування яких майбутніми фахівцями ФКіС дозволять поліпшити управління руховою діяльністю як власною, так і інших.

Аналіз останніх досліджень і публікацій. Аналіз наукових джерел свідчить про те, що упродовж останнього десятиліття дослідники надають значної уваги проблемі професійної освіти у сфері фізичної культури і спорту, зокрема, розкрито: концептуальні основи професійної підготовки фахівців у галузі фізичної культури і спорту (В. Магін, В. Приходько, О. Томенко, С. Хазова та ін.); теоретичні й методичні засади професійної підготовки майбутніх учителів фізичної культури (О. Ажиппо, П. Джуринський, О. Печко та ін.); теоретичні й методичні засади професійної підготовки майбутніх 
фахівців з фізичної реабілітації та фахівців зі здоров'я людини (Н. Бєлікова, Ю. Лянной та ін.); концептуальні засади професійної підготовки майбутніх тренерів-викладачів (Є. Павлюк, А. Сватьєв та ін.). Науковий інтерес для нашого дослідження становлять роботи А. Гладишева, Н. Гущиної, Р. Клопова, В. Пономарьова, Д. Пятницької, О. Сайкіної та ін. щодо методичних аспектів підготовки фахівців різних спеціалізацій для сфери ФКіС в закладах вищої освіти.

Виділення невирішених раніше частин загальної проблеми. Водночас грунтовний аналіз наукових джерел засвідчив, що проблема формування кінезіологічної компетентності майбутніх фахівців ФКіС у процесі їх професійної підготовки не була предметом широкого кола досліджень вітчизняних та зарубіжних науковців.

Мета статті - схарактеризувати сутність і структуру кінезіологічної компетентності майбутніх фахівців фізичної культури і спорту.

Виклад основного матеріалу. Фундаментом фізичної культури і спорту є об’єктивна біологічна потреба людини в руховій активності. Рухова активність - необхідна умова нормального розвитку та функціонування організму. Вона не просто корисна, як ми звикли чути, а життєво необхідна.

Слід зазначити, що предметом дослідження рухової функції людини є наука кінезіологія, яка на системному рівні об'єднує комплексні знання з різних наукових напрямків: анатомо-морфологічних, біомеханічних, фізіологічних, психосоматичних та ін.

У даний момент існують різні точки зору на визначення поняття кінезіології як науки (роботи М.В. Дутчак [3], Р.В. Клопова [5], В.О. Пономарьова [8], Д.В. Пятницької [9], О.Г. Сайкіної [10] та ін.). Враховуючи різні погляди вчених, автор О.І. Загревська [4, с. 55] у своїй науковій праці представила існуючі напрями кінезіології та охарактеризувала предмет вивчення і завдання, які вирішуються в рамках конкретного напряму, на основі чого систематизуємо розробників, які займалися даною тематикою (табл. 1).

Кінезіологія є галуззю біологічного знання з педагогічною спрямованістю й охоплює напрямки: механічні, функціонально-анатомічні, фізіологічні, інструментальні. Як зазначає Д. Д. Донський [2], об’єктом їі пізнання є рухові дії як системи взаємно пов'язаних активних рухів і положень тіла людини, а областю вивчення $є$ механічні і біологічні причини виникнення рухів в їх єдності і особливості їх виконання в різноманітних умовах. Провідними рисами розвитку кінезіології $є$ іiі педагогізація, взаємопроникнення методів та методик дослідження, взаємообмін знаннями, досвідом, розмитість меж навчальних i наукових дисциплін з одночасним розширенням та зміцненням взаємозв'язків між ними. 
Таблиия 1

НАПРЯМКИ РОЗВИТКУ КІНЕЗІОЛОГІЧНОЇ НАУКИ

\begin{tabular}{|c|c|c|c|}
\hline $\begin{array}{c}\text { Напрями } \\
\text { кінезіології }\end{array}$ & $\begin{array}{l}\text { Предмет } \\
\text { вивчення }\end{array}$ & $\begin{array}{c}\text { Завдання, які } \\
\text { вирішуються в } \\
\text { рамках напряму }\end{array}$ & $\begin{array}{c}\text { Представники } \\
\text { (розробники) }\end{array}$ \\
\hline $\begin{array}{c}\text { Прикладна } \\
\text { кінезіологія } \\
\text { (використовує } \\
\text { зв'язки між м'язами } \\
\text { і органами для } \\
\text { виявлення і } \\
\text { усунення різних } \\
\text { порушень) }\end{array}$ & $\begin{array}{l}\text { Вплив рухових } \\
\text { дій на } \\
\text { фізіологічні } \\
\text { системи } \\
\text { організму } \\
\text { людини }\end{array}$ & $\begin{array}{c}\text { Корекція здоров’я } \\
\text { на основі його } \\
\text { взаємозв’язку з } \\
\text { психічними, } \\
\text { емоційними, } \\
\text { моральними і } \\
\text { духовними } \\
\text { аспектами } \\
\text { особистості }\end{array}$ & $\begin{array}{l}\text { Д. Гудхарт, } \\
\text { П. Деннісон, } \\
\text { Г. Деннісон, } \\
\text { I.P. Шмідт, } \\
\text { J. Shafer }\end{array}$ \\
\hline $\begin{array}{c}\text { Спортивна } \\
\text { кінезіологія } \\
\text { (грунтується на } \\
\text { побудові «моделі } \\
\text { оптимальної } \\
\text { техніки» рухової дії) }\end{array}$ & $\begin{array}{c}\text { Спортивна } \\
\text { рухова активність }\end{array}$ & $\begin{array}{c}\text { Удосконалення } \\
\text { технології } \\
\text { навчання } \\
\text { спортивним } \\
\text { руховим діям на } \\
\text { основі інтеграції } \\
\text { їх смислового } \\
\text { образу з зоровим } \\
\text { і кінестетичним }\end{array}$ & $\begin{array}{l}\text { М.А. Бернштейн, } \\
\text { В.Б. Коренберг, } \\
\text { В.К. Бальсевіч, } \\
\text { Х.Х. Гросс і ін. }\end{array}$ \\
\hline $\begin{array}{c}\text { Освітня } \\
\text { кінезіологія } \\
\text { (грунтується на } \\
\text { взаємозв'язку } \\
\text { рухової діяльності } \\
\text { та когнітивної сфери } \\
\text { особистості) }\end{array}$ & $\begin{array}{c}\text { Технологія } \\
\text { застосування } \\
\text { кінезіологічних } \\
\text { засобів в } \\
\text { освітньому } \\
\text { процесі }\end{array}$ & $\begin{array}{c}\text { Розвиток } \\
\text { здатності до } \\
\text { навчання } \\
\text { (поліпшення } \\
\text { читання, письма), } \\
\text { розвиток пам’яті, } \\
\text { мислення і т.д. }\end{array}$ & $\begin{array}{l}\text { Х.Х. Гросс, } \\
\text { Д. Гудхарт, } \\
\text { П. Деннісон, } \\
\text { Г. Деннісон, } \\
\text { В.М. Ірхін, } \\
\text { О.В. } \\
\text { Польщикова } \\
\text { та ін. }\end{array}$ \\
\hline $\begin{array}{c}\text { Онтокінезіологія } \\
\text { (грунтується на } \\
\text { принципах } \\
\text { соціовідповідності } \\
\text { розвитку } \\
\text { кінезіологічного } \\
\text { потенціалу людини) }\end{array}$ & $\begin{array}{c}\text { Фундаментальні } \\
\text { закономірності } \\
\text { вікового розвитку } \\
\text { рухової } \\
\text { діяльності } \\
\text { людини }\end{array}$ & $\begin{array}{c}\text { Удосконалення } \\
\text { рухової } \\
\text { діяльності } \\
\text { людини на різних } \\
\text { етапах його } \\
\text { онтогенезу }\end{array}$ & $\begin{array}{c}\text { М.А. Бернштейн, } \\
\text { В.К. Бальсевіч }\end{array}$ \\
\hline $\begin{array}{l}\text { Педагогічна } \\
\text { кінезіологія } \\
\text { (грунтується на } \\
\text { соціокультурній } \\
\text { теорії рухових дій) } \\
\end{array}$ & $\begin{array}{c}\text { Психосемантика } \\
\text { діяльнісної } \\
\text { свідомості }\end{array}$ & $\begin{array}{c}\text { Смислове } \\
\text { проектування } \\
\text { рухової } \\
\text { діяльності }\end{array}$ & $\begin{array}{l}\text { Х.Х. Гросс, } \\
\text { С.В. Дмитриев, } \\
\text { Д.Д. Донський, } \\
\text { В.Л. Уткін }\end{array}$ \\
\hline
\end{tabular}


Як вказує А.М. Лапутін [6], кінезіологія - це вчення про рухову функцію організму людини. Кінезіологія є синтетичною наукою, у якій з різних точок зору із системних позицій вивчається єдиний об'єкт - рухова функція організму людини. Вона об'єднує в системній єдності такі науки, як морфологія, фізіологія, біомеханіка, біохімія, соматомоторика i дидактика. Причому, основним предметом всіх цих наук $\epsilon$, як правило, рухова функція організму людини.

Автор наголошує, що рухова функція - одна 3 найважливіших функцій організму. Зростання педагогічної спрямованості біомеханіки фізичного виховання i спорту, синтезування знань 3 анатомії, фізіології, фізики, математики, теорії управління, використання досягнень в галузі інформаційнокомунікаційних технологій дають підстави вважати, що кінезіологія служить сполучною ланкою між теорією і практикою фізичного виховання, спорту масової фізичної культури.

Оскільки кінезіологія - міждисциплінарна наука, яка включає біологічні знання (анатомо-морфологічні, фізіологічні) та фізико-математичні (біофізика, механіка, математико-статистичні), то кінезіологічна компетентність має на меті зосередити сформовані узагальнені теоретичні знання і практичні вміння суміжних дисциплін, методики реалізації індивідуальної рухової потреби.

Отже, кінезіологічну компетентність майбутніх фахівців 3 фізичної культури та спорту будемо розуміти як складову їх професійної компетентності, інтегральну особистісну якість, яка проявляється у поєднанні ціннісних поведінкових установок на раціональне виконання рухових дій i прагнення до фізичного розвитку й саморозвитку, спеціальних (кінезіологічних) знань і вмінь та методичних навичок їхнього розвитку в себе та інших, а також навичок рефлексії щодо оцінки ефективності рухової активності.

Під формуванням кінезіологічної компетентності майбутніх фахівців 3 фізичної культури та спорту будемо розуміти динамічний процес якісних $\mathrm{i}$ кількісних особистісних змін у майбутніх фахівців ФКіС, що відбуваються за умов їх мотивації на формування кінезіологічної компетентності як професійно пріоритетної у професійній діяльності та зорієнтований на опанування спеціальних кінезіологічних знань і вмінь. Результатом такого формування $\epsilon$ цілісне особистісне утворення, яке забезпечує ефективне вирішення професійних завдань майбутніми фахівцями ФКіС [7].

В якості структурних компонентів кінезіологічної компетентності майбутніх фахівців фізичної культури і спорту слід виокремити:

1) гносеологічний компонент (сприйняття, осмислення і відображення кінезіологічних знань, а також біомеханічне моделювання рухової активності);

2) праксеологічний компонент (кінезіологічні уміння i досвід самостійного застосування різних засобів у навчальній і професійній діяльності, здатність конструювання педагогічного процесу навчання руховим діям та їх корекції); 
3) поведінковий компонент (професійні мотиви, позиції, установки, цінності, прагнення досконалості професійної діяльності у формуванні рухових дій, професійно необхідні особистісні якості для педагогічної взаємодії, коректної оцінки процесу і результату своєї діяльності, власних професійних можливостей).

Варто наголосити, що формування кінезіологічної компетентності фахівців з фізичної культури та спорту сприяє реалізації таких завдань [1]: оцінка фізичних вправ 3 точки зору їх ефективності у вирішенні основних завдань шкільної фізкультурної освіти; вивчення техніки фізичної вправи 3 виявленням головного елементу рухів, що забезпечує необхідний результат; оцінка якості виконання фізичних вправ, виявлення помилок, їх причин та наслідків; виявлення найкращих зразків техніки фізичних вправ; теоретичне обгрунтування можливості удосконалення спортивної техніки; вивчення функціональних показників фізичної підготовки 3 метою визначення шляхів підвищення функціональних можливостей людини.

Висновки. Отже, нами обгрунтовано поняття та структуру кінезіологічної компетентності майбутніх фахівців 3 фізичної культури та спорту, що формується у ЗВО. Виокремлено гносеологічний, праксеологічний та поведінковий компоненти, які мають взаємозалежний та взаємопов'язаний характер.

Перспективи подальших досліджень. У подальшому слід представити шляхи формування та розвитку кінезіологічної компетентності майбутніх фахівців з фізичної культури та спорту.

\section{Jimepamypa}

1. Ажиппо О. Ю. Сучасний стан i проблеми індивідуалізованого навчання студентів. Педагогіка формування творчої особистості у вищих $i$ загальноосвітній школах. Запоріжжя : КПУ, 2015. Вип. 42 (95). С. 506-513.

2. Донской Д. Д., Зациорский В. М. Биомеханика. Москва : Физкультура и спорт, 1979. $264 \mathrm{c}$.

3. Дутчак М. В. Теоретико-методологічні засади формування системи спорту для всіх в Україні : автореф. дис.... д-ра пед. наук. 13.00.04. Київ : Національний університет фізичного виховання і спорту України, 2009. 38 с.

4. Загревская А. И. Физкультурно-спортивное образование студентов на основе кинезиологического подхода. Томск: Издательский Дом Томского государственного университета, 2015.

5. Клопов Р.В. Професійна підготовка майбутніх фахівців фізичного виховання i спорту із застосуванням інформаційних технологій: теорія i практика / за ред. С.О. Сисоєвої. Запоріжжя: Запорізький національний унів-т, 2010. $386 \mathrm{c}$.

6. Лапутин А.Н. Кинезиология - учение о двигательной функции организма человека. Педагогика, психология и медико-биологические проблемь физического воспитания и спорта. 2007. № 4. С. 3-6. 
7. Петренко Ю. І. Основні структурні компоненти кінезіологічної компетентності майбутніх фахівців фізичної культури і спорту. Педагогічні науки: теорія, історія, інноваційні технології. Суми : Вид-во СумДПУ імені А.С. Макаренка, 2018. №5 (79). С.184-199.

8. Пономарьов В. О. Формування професійно-педагогічної компетентності майбутнього тренера з атлетичної гімнастики у процесі фахової підготовки : автореф. дис. ... канд. пед. наук : 13.00.04. Запоріжжя, 2010. 20 с.

9. П'ятницька Д. В. Аналіз форм організації навчального процесу майбутніх фітнес-тренерів. Педагогіка формування творчої особистості у вищій $і$ загальноосвітній школах. 2016. № 47. С. 322-328.

10.Сайкина Е. Г. Концептуальные основы подготовки специалистов по фитнесу в современных социокультурных условиях : монография. СанктПетербург : Изд-во РГПУ им. А. И. Герцена, 2007. 393 с.

\section{References}

1. Azhippo, O.Y. (2015). The current state and problems of individualized student learning. Pedagogy of formation of creative personality in higher and secondary schools, 42 (95), 506-513.

2. Donskoy, D.D., \& Zatsiorsky, V.M. (1979). Biomechanics. Moscow : Physical Culture and Sports.

3. Dutchak, M.V. (2009). Theoretical and methodological principles of formation of the sports system for all in Ukraine: dis.... dr. ped. science. 13.00.04. Kyiv: National University of Physical Education and Sport of Ukraine.

4. Zagrevskaya, A.I. (2015). Physical education of students on the basis of a kinesiological approach. Tomsk: Tomsk State University Publishing House.

5. Klopov, R.V. (2010). Professional training of future specialists in physical education and sports with the use of information technology: theory and practice / ed. S. O. Sysoeva. Zaporozhye: Zaporozhye National University.

6. Laputin, A.N. (2007). Kinesiology - the study of the motor function of the human body. Pedagogy, psychology and medical and biological problems of physical education and sports, 4, 3-6.

7. Petrenko, Y.I. (2018). The main structural components of kinesiological competence of future specialists in physical culture and sports. Pedagogical sciences: theory, history, innovative technologies. Sumy: Published by Sumy State Pedagogical University named after Makarenko, №5 (79),184-199.

8. Ponomarev, V.O. (2010). Formation of professional and pedagogical competence of the future coach in athletic gymnastics in the process of professional training: dis. ... cand. ped. science: 13.00.04. Zaporozhye.

9. Pyatnytska, D.V. (2016). Analysis of forms of organization of the educational process of future fitness trainers. Pedagogy of formation of creative personality in higher and general education schools, 47, 322-328.

10. Saikina, E.G. (2007). Conceptual bases of training of experts in fitness in modern sociocultural conditions. St. Petersburg: RGPU Publishing House. AI Herzen. 